\title{
O Nôvo Esquema da Revista do Serviço Público
}

ONFORME foi anunciado, a R.S.P., a partir da edição correspondente ao segundo trimestre de 1961 (abril, maio e junho), passou a circular trimestralmente. Ao mesmo tempo, adotou outra maneira de classificar e ordenar a matéria constante de suas edições. O nôvo esquema, desdobrado em duas partes, a primeira e principal dedicada à administração geral, núcleo de interêsse da R.S.P., a segunda e subsidiária aberta à administração especifica, também suscetivel de oferecer contribuições valiosas ao estudo das modernas técnicas administrativas, compreende os seguintes:

\section{ELEMENTOS PERMANENTES}

Editorial - A R.S.P. manterá a tradição de abrir cada número com um editorial, em que, como porta-voz do D.A.S.P., opinará sôbre as questões administrativas mais palpitantes do momento. Os editoriais deverão primar pela sobriedade da linguagem, objetividade dos argumentos, procedência das críticas, realismo dos comentários e atualidade e idoneidade da doutrina.

\section{Primeira Parte}

ADMINISTRAÇÃO GERAL

Estudos Gerais - Esta seção incluirá estudos gerais, teóricos, históricos ou descritivos, sôbre temas amplos de administração, seu ensino, sua teoria e sua prática. Destina-se a abrigar os trabalhos de administração-geral não enquadráveis em nenhuma das seções especializadas abaixo.

Funções de Chefia - Incluir-se-ão nesta seção ensaios teóricos e estudos pragmáticos (casos) sôbre as funções de chefia, a saber: direção, coordenação e contrôle.

Serviços de Estado-Maior - Esta seção subordinará artigos doutrinários e estudos pragmáticos sôbre os Serviços de EstadoMaior, nomeadamente a pesquisa administrativa, a previsão, o planejamento, a elaboração orçamentária, a organização, os métodos de trabalho, e o assessoramento em geral. 
Serviços Auxiliares - Esta seção compreenderá ensaios doutrinários, estudos pragmáticos, relatórios etc., sôbre os meios materiais de ação administrativa. Tudo que tratar de administração de pessoal, administração financeira, administração de material, administração patrimonial, administração documental (biblioteca e arquivo) e outros serviços auxiliares será publicado como parte desta seção.

Relações Públicas - Esta seção incluirá artigos doutrinários, estudos pragmáticos e relatórios sôbre serviços de Relações Públicas.

Registro Administrativo - Esta seção registrará os fatos administrativos mais importantes que ocorrerem no serviço público do país .

Marcha da Administração Científica - Esta seção conterá críticas de livros e notícias bibliográficas. Cada edição da Revista trará pelo menos uma crítica de livro nôvo sôbre matéria administrativa. Transcrições, notícias bibliográficas e resumos de artigos publicados em órgãos similares no Brasil e no estrangeiro poderão também aparecer aqui.

Jurisprudência Administrativa - Esta seção, tradicional na Revista, conterá pareceres e acórdãos selecionadoz sôbre casos e questões administrativas.

\section{Segunda Parte}

\section{ADMINISTRAÇÃO ESPECÍFICA}

Além de tratar dos temas de Administração-Geral enumerados acima, a R.S.P. incluirá, sempre que oportuno, artigos, estudos, relatórios e notícias sôbre ocorrências verificadas no campo da Administração Especifica.

\section{O MODUS FACIENDI}

Ao planejar cada edição da Revista, a sua Direção determinará a freqüência com que os diferentes tópicos integrantes das seções deverão ser objeto de ensaios e estudos. Uma política vigilante impedirá que certos temas sejam supercontemplados e outros negligenciados. A direção da Revista dosará o tratamento dos diferentes temas em que se subdividem as seções.

O progresso das técnicas administrativas deverá refletir-se pronto nas páginas da Revista. $\mathrm{O}$ aperfeiçoamento de uma doutrina ou o advento de uma técnica administrativa nova - por exemplo: o orçamento de execução (performance budget) deverá ser objeto de interêsse da Revista, e êsse interêsse deverá assumir a forma militante de ensaios, estudos, notícias, críticas etc. 
Trata-se, como se vê, de um esquema flexível, modulado, adaptado à nova política editorial da R.S.P., que orientará a disposição dos ensaios, estudos, artigos, notícias e informações dentro de seções especializadas.

Baseia-se o esquema, além disso, na mais autorizada divisão da administração científica, estando de acôrdo, inclusive, com o currículo dos melhores cursos de Administração Geral até agora instituídos.

O esquema é permanente, mas só raramente aparecerá completo (com tôdas as seções), nos diferentes números da Revista. Todavia, uma edição típica da Revista conterá, no minimo, quatro artigos e estudos sôbre duas ou mais das cinco primeiras seções, isto é:

- Estudos Gerais

- Funções de Chefia.

- Serviços de Estado-Maior.

- Serviços Auxiliares

- Relações Públicas.

Assim sendo, aparecerão no sumário de cada edição sòmente as seções que veicularem ensaios ou artigos contidos na mesma. $\mathrm{Na}$ edição passada, correspondente ao quarto trimestre de 1961 , por exemplo, apareceram no sumário apenas as seções - Estudos Gerais, Serviços de Estado-Maior, e Serviços Auxiliares. Na presente edição, figuram: Estudos Gerais, Funções de Chefia, S'erviços Auxiliares.

As Seções Registro Administrativo, Marcha da Administração Cientifica e Jurisprudência Administrativa figurarão em tôdas as edições. Serão distintivos permanentes da R.S.P.

A Segunda Parte, Administração Especifica, será acrescentada a uma edição sòmente quando houver matéria de interêsse excepcional sôbre qualquer das modalidades da administração específica, notadamente da escolar, hospitalar, rodoviária, ferroviária, sanitária e outras de igual relêvo. Neste número, por exemplo, inclui-se o estudo de Jean Nepote, intitulado Coordenação dos Serviços de Polícia no Brasil.

O esquema será, assim, integralizado com periodicidade variâvel, por um número igualmente variável de edições da R.S.P. Ocasionalmente, quando as circunstâncias forem ideais, uma única edição poderá apresentar o esquema completo (com tôdas as seções).

Esperamos que o nôvo arranjo contribua para o prestígio de nossa veterana publicação, assim como para o progresso profissional dos leitores. 